Ius Matrimoniale 32 (2021) nr 2

ISSN 1429-3803; e-ISSN 2353-8120

DOI: http://doi.org/10.21697/im.2021.32.2.05
Artykuł jest udostępniany na zasadach licencji Creative Commons (CC BY-ND 4.0 Międzynarodowe) https://creativecommons.org/licenses/by-nd/4.0/deed.pl

\title{
Przeszkody do zawarcia związku małżeńskiego w dokumencie o małżeństwie Wielkiego Soboru Kościoła Prawosławnego, Kreta 2016
}

\author{
Impediments to getting marriage in the document of Grand Council \\ of the Orthodox Church, Crete 2016
}

\author{
Ks. Andrzej Kuźma \\ Chrześcijańska Akademia Teologiczna w Warszawie \\ ORCID: 0000-0003-4485-9821 \\ e-mail: a.kuzma@chat.edu.pl
}

Streszczenie: W artykule została przedstawiona krótka historia powstania tekstu o małżeństwie, który został przyjęty na Soborze Kościoła Prawosławnego na Krecie w 2016 roku. Druga część tego dokumentu wymienia przeszkody, które stanowią przeszkody w zawarciu związku małżeńskiego. Dokument z Krety wymienia pięć przeszkód: pokrewieństwo i powinowactwo, brak unieważnienia poprzedniego małżeństwa, śluby zakonne, kapłaństwo, związki mieszane wyznaniowo i religijnie. W artykule wskazano również na kontrowersje związane z pewnymi rozbieżnościami w świecie prawosławnym dotyczącymi postrzegania kapłaństwa jako przeszkody w zawarciu małżeństwa jak też postrzegania związków małżeńskich mieszanych wyznaniowo.

Słowa kluczowe: Sobór Kościoła Prawosławnego, małżeństwo w prawosławiu, przeszkody w zawarciu małżeństwa.

Abstract: The article found a short history of text "The Sacrament of Marriage and its Impediments", which was adopted at the Council of the Orthodox Church in Crete in 2016. The second part of this document lists the factors that are impediments to getting married. The Crete document lists five obstacles: kinship by blood and kinship by affinity, no nullity of a previous marriage, monastic vows, priesthood, mixed marriages. The article also points to the controversy related to certain divergences in the Orthodox word regarding the perception of the priesthood as an obstacle to marriage, as well as the perception of mixed marriages with non-Orthodox Christians.

Keywords: Council of the Orthodox Church, marriage in Orthodoxy, impediments to getting marriage

Treść: Wstęp. 1. Historia przygotowania tekstu. 2. Ostateczna wersja dokumentu. 3. Przeszkody do zawarcia małżeństwa. 3.1. Pokrewieństwo i powinowactwo. 3.2. Drugie i trzecie 
małżeństwo. 3.3. Postrzyżyny mniejsze. 3.4. Małżeństwo duchownych. 3.5. Małżeństwo mieszane. Podsumowanie.

\section{Wstęp}

W dniach 18-26 czerwca 2016 roku, po wielu latach przygotowań odbył się na wyspie Kreta (Grecja), pod przewodnictwem Patriarchy Ekumenicznego Bartłomieja, Wielki i Święty Sobór Kościoła Prawosławnego. W swoim zamierzeniu Sobór miał być manifestacją i utwierdzeniem jedności Kościoła prawosławnego we współczesnym świecie. Plany te jednak w zupełności nie zostały zrealizowane ze względu na odmowę w uczestnictwie czterech spośród czternastu lokalnych Kościołów autokefalicznych. Sobór jednak odbył się przy udziale dziesięciu lokalnych Kościołów i rezultatem tego zdarzenia eklezjalnego jest przyjęcie ośmiu dokumentów, które dotykają różnych sfer współczesnego życia Kościoła prawosławnego ${ }^{1}$. Wśród dokumentów, które zostały przyjęte na Soborze, jest dokument odnoszący się do zagadnienia sakramentu małżeństwa zatytułowany: "Sakrament małżeństwa i jego przeszkody” 2 . Dokument zasadniczo składa się z dwóch części - pierwsza: „Prawosławne małżeństwo” i druga: „Przeszkody małżeńskie”. Tekst tego dokumentu, jeszcze w fazie projektu, został omówiony przez autora niniejszej publikacji jako całość ${ }^{3}$ W obecnym opracowaniu chciałbym pochylić się nad

1 Opis przebiegu Soboru i charakterystyka przyjętych dokumentów por. A. Kuźma, Wielki Sobór Kościoła Prawosławnego na Krecie w 2016 r. i jego ustalenia, ELPIS 20 (2018), s. 165-179.

${ }^{2}$ Wszystkie dokumenty zostały opublikowane w czterech językach oficjalnych (grecki, rosyjski, angielski i francuski) na stronie Official Documents of the Holy and Great Council of the Orthodox Church, https://www.holycouncil.org/official-documents [dostęp 5.05.2021]. Tłumaczenie polskie dokumentu: Sakrament matżeństwa i jego przeszkody, w: Cerkiewny Wiestnik, Wydawnictwo Warszawskiej Metropolii Prawosławnej nr 4/2016, s. 50-53.

3 Por. A. Kuźma, Małżeństwo w projektach dokumentów na Wszechprawosławny Sobór, ELPIS 16 (2016), s. 177-182. 
sprawą samych przeszkód w zawarciu małżeństwa, już w wersji przyjętego dokumentu przez Sobór.

\section{Historia przygotowania tekstu}

Katalog tematów, którymi powinien zająć się Wielki Sobór Kościoła Prawosławnego, został zdefiniowany na Pierwszej Ogólnoprawosławnej Konferencji Przedsoborowej w 1976 roku, która odbyła się w Chambésy koło Genewy. Spis tematów, który wówczas został sporządzony i zaakceptowany, zawierał dziesięć punktów, gdzie zagadnienie małżeństwa zajmowało szóste miejsce ${ }^{4}$. Problematyka małżeństwa była też jednym z pierwszych tematów, które zostały opracowane i przyjęte przez kolejną Ogólnoprawosławną Konferencję Przedsoborową jako oficjalny projekt dokumentu na przyszły Sobór. Konferencja ta odbyła się w 1982 roku, również w Chambésy. Dokument w swojej pierwotnej wersji nosił krótki tytuł: „Przeszkody małżeńskie"5. Jego autorzy w jego pierwotnej wersji zamierzali więc skupić się jedynie na problemach kanonicznych, które stanowiły lub mogły stanowić przeszkody do zawarcia związku małżeńskiego. Dokument ten w wersji projektu, w późniejszym okresie otrzyma jednak nieco zmieniony tytuł i odniesie się w szerszym kontekście do zagadnienia małżeństwa.

Większość zagadnień traktujących o przeszkodach w zawarciu związku małżeńskiego, które wystąpiły w projekcie z 1982 roku, zostało ujętych w dokumencie z 2016 roku. Warto jednak zwrócić uwagę na dyskusję, która miała miejsce w czasie tworzenia pierwszego projektu w 1982 roku. Prawdopodobnie zamiarem części uczestników II Konferencji (1982) było wprowadzenie znaczących zmian w określeniu przeszkód w zawieraniu związków małżeńskich. Te znaczące

4 Por. Synodica III, Secretariat pour la preparation du Saint et Grande Concile de l'Eglise Orthodoxe, Chambésy-Genève 1979, s. 114.

5 Por. Przeszkody małżeńskie, Tekst przyjęty przez II Ogólnoprawosławną Konferencję Przedsoborową (Chambésy 1982), w: T. KAŁUŻny, Nowy Sobór Ogólnoprawosławny, Kraków 2008, s. 398-399. 
zmiany miałyby zawierać się w możliwości zawarcia związku małżeńskiego: a) osobom, które posiadają święcenia diakońskie i b) zawarcie ponownego małżeństwa owdowiałym kapłanom ${ }^{6}$. Kościół prawosławny nie zabrania duchownym (diakonom i prezbitrom) wstępowania w związek małżeński, lecz zgodnie z kanonem in Trullo 6 taki związek powinien być zawarty jeszcze zanim zostaną udzielone święcenia diakońskie lub prezbitra ${ }^{7}$. W wyniku dyskusji, która rozwinęła się w czasie tego spotkania, stwierdzono, że zezwolenie zawierania małżeństwa przed święceniami diakońskimi, jak też pozwolenie owdowiałym kapłanom wstępowania w nowy związek małżeński będzie znaczącym naruszeniem tradycji kanonicznej i w rzeczywistości będzie złamaniem starożytnych kanonów. Dlatego też projekt dokumentu, który był rezultatem II Konferencji Ogólnoprawosławnej z 1982 roku nie zawierał tych kontrowersyjnych innowacji ${ }^{8}$. Punkt 6 dokumentu brzmiał: „Kapłaństwo na każdym z trzech stopni, stanowi przeszkodę do zawarcia małżeństwa, zgodnie z obowiązującą tradycją kanoniczną"9.

Proces przygotowawczy do Soboru trwał jednak wiele lat i miał wiele swoich etapów. W 2014 roku w Konstantynopolu odbyło się spotkanie wszystkich Zwierzchników Lokalnych Autokefalicznych Kościołów Prawosławnych (Synaxa). Na spotkaniu tym postanowiono znacząco przyśpieszyć przygotowania do planowanego Soboru. Zauważono jednak, że wiele spośród wcześniej przygotowanych i zatwierdzonych dokumentów potrzebuje pewnych zmian, lub też gruntownych przeformułowań. Dokument „Przeszkody małżeńskie” został zakwalifikowany do tej grupy, gdzie wprowadzone zmiany miały być niewielkie ${ }^{10}$. Synaksa Zwierzchników powołała Specjalną Komisję, której zadaniem było przeredagowanie i uzupełnienie do-

\footnotetext{
6 Por. Synodica VIII, Secretariat pour la preparation du Saint et Grande Concile de l'Eglise Orthodoxe, Chambésy-Genève 1994, s. 125.

7 Por. Kanony Kościoła Prawosławnego, tłum. A. Znosko, Hajnówka 2000, s. 71.

8 Por. Przeszkody małżńskie..., s. 389-399.

9 Tamże, s. 399.

10 Por. Decyzja Zwierzchników Cerkwi Prawosławnych, Wiadomości Polskiego Autokefalicznego Kościoła Prawosławnego (2014) nr 4, s. 3.
} 
kumentów w taki sposób, by stały się one gotowymi projektami na planowany Sobór. Dokument dotyczący małżeństwa stał się obiektem dyskusji dopiero w czasie trzeciego spotkania Komisji (29 marca 4 kwietnia 2015).

W opinii uczestników spotkania, reprezentujących wszystkie autokefaliczne lokalne Kościoły prawosławne, główną niedoskonałością dokumentu był brak wyrażeń, które w pozytywny sposób postrzegałyby instytucję małżeństwa i rodziny. Wskazywano, że w obecnych czasach nie wystarczy mówić jedynie o przeszkodach do zawarcia związku małżeńskiego, lecz należy podkreślić wartość i ważność tego Bożego ustanowienia. Efektem tego spotkania nie było jednak rozszerzenie dokumentu o nowe punkty ${ }^{11}$.

Omawiany dokument został jednak znacząco zmieniony i rozszerzony na spotkaniu Zwierzchników Lokalnych Kościołów Prawosławnych, które właściwie było ostatnim etapem w procesie przygotowawczym do Soboru. Miało ono miejsce w styczniu 2016 roku, w Chambésy koło Genewy ${ }^{12}$. Uczestnicy tego spotkania postanowili wprowadzić rozdział, w którym zostałoby wyartykułowane pojmowanie małżeństwa w opcji fundamentu rodziny w Kościele prawosławnym. W ten sposób po Synaksie Zwierzchników w styczniu 2016 roku, dokument o małżeństwie stał się oficjalnym projektem dokumentu na Sobór Kościoła Prawosławnego z nowym tytułem: „Sakrament małżeństwa i przeszkody do jego zawarcia”"13 nie dotykał on już jedynie przeszkód do zawarcia związku małżeńskiego, lecz

\footnotetext{
11 Por. A. Kuźma, Trzecie spotkanie Komisji Przygotowawczej, Wiadomości Polskiego Autokefalicznego Kościoła Prawosławnego (2015) nr 5, s. 7.

12 Por. Synaksa Zwierzchników Lokalnych Cerkwi Prawosławnych, Chambésy (21-28 stycznia 2016), Wiadomości Polskiego Autokefalicznego Kościoła Prawosławnego (2016) nr 3, s. 4.

${ }^{13}$ Tłumaczenie, którym posługuję się w niniejszym opracowaniu: Sakrament małżeństwa i przeszkody do jego zawarcia. Tekst przyjęty przez uczestników zgromadzenia (Synaxis) zwierzchników autokefalicznych Kościołów prawosławnych (Chambésy 2016), tłum. pol. T. KaŁużny, w: T. KaŁużny, Z. KiJas (red.), Przed Soborem Wszechprawosławnym, Kraków 2016, s. 267-271.
} 
traktował ten sakrament w szerszym kontekście wskazując również na pewne pasterskie i duchowe uwarunkowania.

\section{Ostateczna wersja dokumentu}

Dokument „Sakrament małżeństwa i przeszkody do jego zawarcia" nie stanowił większego problemu w dyskusji soborowej. Pewną rozbieżność poglądów można było zaobserwować jedynie w czasie dyskusji o możliwości powtórnego zawierania małżeństwa przez duchownych i legalności zawierania małżeństw mieszanych wyznaniowo ${ }^{14}$. Projekt dokumentu przyjęty przez Synaksę zwierzchników w styczniu 2016 roku stał się podstawą dokumentu przyjętego przez Sobór. Wyjątek stanowił punkt dotyczący legalności związków małżeńskich mieszanych wyznaniowo, który uległ pewnym zmianom. Zagadnienie to zostanie przedstawione nieco niżej. Dyskusja i przyjęcie dokumentu miało miejsce w czasie obrad plenarnych 23 czerwca 2016 roku.

Pierwsza część dokumentu nie jest obiektem naszego zainteresowania, dlatego też należałoby odnieść się do części drugiej, wyrażającej współczesną praktykę Kościoła prawosławnego w obszarze przeszkód do zawarcia małżeństwa. Generalnie, w dokumencie przyjętym przez Sobór zostały zachowane te punkty, które były zawarte w dokumencie przyjętym przez II Konferencję Ogólnoprawosławną (1982). Niektóre z tych punktów zostały nieco zmodyfikowane i przeformułowane. Dokument wylicza pięć punktów, które stanowią przeszkodę w zawarciu związku małżeńskiego.

\footnotetext{
14 Na obecnym etapie braku stenogramów z Soboru, trudno rozwinąć zagadnienie w sposób bardziej udokumentowany i merytoryczny. Niniejsze stwierdzenia są rezultatem notatek i zapisów autora artykułu, który wchodził w skład delegacji Polskiego Autokefalicznego Kościoła Prawosławnego na Wielki Sobór Kościoła Prawosławnego.
} 


\section{Przeszkody do zawarcia małżeństwa}

\subsection{Pokrewieństwo i powinowactwo}

Jako pierwsze przeszkody do zawarcia związku małżeńskiego ukazane zostały powody wynikające z pokrewieństwa, powinowactwa i adopcji. Dokument w swojej treści odsyła do przepisów kanonów 53 i 54 Soboru Trulliańskiego. Kanon 53 zabraniał wstępowania w związek małżeński ojcu (lub matce) chrzestnemu dziecka $\mathrm{z}$ owdowiałym rodzicem biologicznym chrzczonego dziecka ${ }^{15}$. Ta przeszkoda, określana jako pokrewieństwo duchowe, jest stosowana we współczesnej praktyce Kościoła prawosławnego ${ }^{16}$. Kanon 54 natomiast rozwijał zagadnienie pokrewieństwa wynikającego z więzów krwi i powinowactwa, zabraniając wstępowania w związek „z córką brata swego; ojca i syna $z$ matką i córką, lub dwóch sióstr z ojcem i synem, lub z dwóch braci z matką i córką; lub dwóch braci z dwiema siostrami" "17. Najbardziej problematycznym w tym kontekście pozostaje zapis wskazujący na zakaz zawierania związku małżeńskiego „Z córką brata swego". Ogólnie takie pokrewieństwo jest bardzo bliskie, stanowiąc trzeci stopień pokrewieństwa w linii bocznej. Z kanonu 54 wynikałoby, że związek małżeński można zawierać już od kolejnego stopnia, tj. od czwartego. We współczesnej praktyce kościelnej stosowanej w większości Kościołów lokalnych zezwala się na zawarcie małżeństwa poczynając od piątego stopnia pokrewieństwa. Do zawarcia jednak małżeństwa osobom będącym w piątym lub szóstym stopniu pokrewieństwa potrzebna jest zgoda biskupa ${ }^{18}$. W kolejnych stopniach taka zgoda nie jest już potrzebna. Jednak, jak wynikało z dyskusji przy opracowywaniu tego dokumentu, w niektórych Kościołach lokalnych nie zezwala się na zawarcie związku osobom będącym w piątym stopniu pokrewieństwa, lecz zezwala się za zgodą biskupa na zawarcie

\footnotetext{
15 Por. Kanony Kościoła prawosławnego..., s. 90.

16 Por. S. Hrycuniak, Prawosławne pojmowanie małżeństwa, Białystok 1994, s. 96.

17 Kanony Kościoła prawosławnego..., s. 90.

18 Por. A. Znosko, Prawosławne Prawo Kościelne, cz. II, Warszawa 1975, s. 75.
} 
związku małżeńskiego osobom od szóstego stopnia pokrewieństwa ${ }^{19}$. Dokument soborowy nie wskazuje stopnia pokrewieństwa, od którego zezwala się na zawarcie związku małżeńskiego. Powołanie się na 54 kanon Soboru in Trullo właściwie nie rozwiązuje problemu. W ten sposób sygnatariusze dokumentu unikają jednoznacznego wskazania, od którego stopnia pokrewieństwa może być zawarty związek małżeński. Dlatego też głównym wyznacznikiem rozwiązania kwestii pozostaje „praktyka kościelna w takiej postaci, w jakiej jest obecnie stosowana w lokalnych autokefalicznych Kościołach prawosławnych oraz określona i opisywana w ich statutach oraz decyzjach ich synodów” (II,1). Tym samym na poziomie ogólnoprawosławnym nie udało sią określić jednoznacznie stosunku do przeszkód w zawarciu związku małżeńskiego wynikających z pokrewieństwa. Należałoby nadmienić, że projekt dokumentu o przeszkodach w zawarciu związku małżeńskiego przedłożony przez II Ogólnoprawosławną Konferencję Przedsoborową w 1982 roku, był bardziej precyzyjny w tej sprawie i wyraźnie wskazywał na piąty stopień pokrewieństwa, od którego można byłoby zawierać związek małżeński ${ }^{20}$.

\subsection{Drugie i trzecie małżeństwo}

Kolejna przeszkoda wyrażona w prezentowanym dokumencie dotyczy drugiego i trzeciego małżeństwa. Kościół prawosławny zezwala na zawarcie drugiego małżeństwa, a nawet trzeciego. Drugie lub trzecie małżeństwo ma charakter pokutny; jest dopuszczalne ze względu na ekonomię kościelną (miłosierdzie wobec człowieka) ${ }^{21}$. Temat ten jest niezwykle ważnym w kontekście współczesnej problematyki związanej z rosnącą liczbą rozwodów ${ }^{22}$. Dokument przyjęty na Krecie w 2016

\footnotetext{
19 Takie stanowisko wyraża Patriarchat serbski i Kościół cypryjski. Por. A. KuźmA, Trzecie spotkanie Komisji Przygotowawczej, Wiadomości Polskiego Autokefalicznego Kościoła Prawosławnego (2015) nr 5, s. 7.

20 Por. Przeszkody małżéskie..., s. 398.

21 Por. A. Znosko, Prawosławne Prawo Kościelne..., s. 68-69.

22 W nauczaniu Kościoła prawosławnego wskazuje się, że sakrament małżeństwa jest nierozerwalnym. Związek dwojga ludzi zawarty w Kościele posiada wymiar
} 
roku stwierdza, że drugie lub trzecie małżeństwo może być zawarte jedynie w przypadku, gdy poprzednie zostało unieważnione. Brak unieważnienia takiego małżeństwa skutkuje kwalifikacją osoby wstępującej w taki związek jako „bigamisty”. Bez względu na okoliczności zaistnienia przerwania związku małżeńskiego (rozwód lub wdowieństwo) nie zezwala się na zawarcie czwartego związku małżeńskiego: „zgodnie z prawosławną tradycją kanoniczną, która kategorycznie potępia dwużeństwo oraz czwarte małżeństwo" (II,2).

\subsection{Postrzyżyny mnisze}

Trzecią przeszkodą, którą wymienia dokument, są złożone śluby zakonne. Wyrażony zakaz nie jest czymś nowym. Wpisuje się raczej w starożytną tradycję kanoniczną. Sygnatariusze dokumentu powołują się przy tym na kanon IV Soboru powszechnego $(I V, 16)$ jak też Soboru in Trullo (44). Wymienione kanony jednak w taki bezpośredni i rygorystyczny sposób nie odnosiły się do tej kwestii. Kanon IV,16 stanowił: „Dziewicy, która poświęciła się Bogu, jak również tym, którzy przyjęli stan zakonny nie wolno wstępować w związek małżeński. Kto tak uczyni, niech będzie wyłączony ze społeczności kościelnej. Zresztą postanowiliśmy, aby lokalny biskup miał pełnię władzy okazać względem takowych miłosierdzie" ${ }^{23}$. Kanon Soboru in Trullo z kolei nakazywał karać mnichów, którzy wstąpili w związek małżeński, karą przewidzianą dla cudzołożników ${ }^{24}$. Natomiast kanon

eschatologiczny. Śmierć jednego z małżonków nie zwalnia drugiego z raz powziętego zobowiązania i nie czyni go „wolnym”. W ten sam sposób rozwód (lub zdjęcie błogosławieństwa), który jest wynikiem zaniku miłości również nie czyni „wolnym” danej osoby. Jednak ze względu na słabość ludzką Kościół dopuszcza zawarcie ponownego związku, argumentując to charakterem odstępstwa (ekonomii) od norm kościelnych. Por. J. Meyendorff, Małżństwo w prawosławiu. Liturgia teologia, życie.; tłum. pol. K. LEŚNIEWSKI, Lublin 1995, s. 52-56.

23 Kanony Kościoła prawosławnego..., s. 58.

24 Por. Tamże, s. 87: „Mnich, któremu zostało dowiedzione cudzołóstwo, albo wstępujący w związek małżeński z kobietą, zgodnie z kanonami podlega karze dla cudzołożników”. 
IV,16 w tym względzie kieruje rozwiązanie problemu do lokalnego biskupa. Znacznie mniej rygorystycznie brzmiał projekt dokumentu przygotowany w 1982 roku: „Konferencja proponuje dopuścić możliwość zawarcia małżeństwa przez tych, którzy opuściwszy - dobrowolnie lub nie dobrowolnie, a także w wypadku wyższej konieczności swój mniszy stan, zostali zredukowani przez odpowiednią decyzję kościelną do stanu świeckiego"25. Należy nadmienić, że powyższa propozycja nie dotyczyła mnichów, którym został udzielony sakrament kapłaństwa. Porównując pierwotny projekt dokumentu i jego ostateczne brzmienie w tej kwestii, obserwuje się bardziej rygorystyczne i tradycyjne podejście.

\subsection{Małżeństwo duchownych}

Dokument w krótki i zwięzły sposób wskazuje, że zawarcie małżeństwa przez osoby duchowne jest niemożliwym: „Kapłaństwo samo w sobie nie stanowi przeszkody do zawarcia małżeństwa, ale zgodnie z obowiązującą tradycją kanoniczną (in Trullo 3), po chirotonii zakazuje się zawierania małżeństwa" (II,4). Dokument nie wskazuje, o jakich stopniach kapłańskich jest mowa. Zgodnie z tradycją kanoniczną święcenia mogą być udzielone prezbiterowi, diakonowi lub ipodiakonowi, którzy zawarli wcześniej związek małżeński. (in Trullo 13). Żonaci biskupi w Kościele byli do VII w. Dopiero kanony Soboru Trulliańskiego (692 rok) wprowadziły formalny wymóg bezżeństwa biskupów (in Trullo 48).

Nieco wyżej wskazywałem na aktualność tego zagadnienia, podkreślając dyskusje i zamiar wprowadzenia możliwości zawarcia związku małżeńskiego po święceniach diakońskich i dla owdowiałych księży, które miały miejsce w 1982 roku. Dyskusja ta powróciła również w czasie obrad Soboru na Krecie (2016). Wydaje się, że w opinii biskupów patriarchatu Konstantynopola, temat ten jest ciągle aktualny i wymagający nowych regulacji. Przeważający jednak

${ }^{25}$ Przeszkody małżeńskie..., s. 398, A. Znosko, Prawosławne Prawo Kościelne..., s. 68 . 
głos większości biskupów z pozostałych Kościołów autokefalicznych wskazywał na nienaruszalność tych norm i pozostawanie w zgodzie $\mathrm{z}$ tradycją kanoniczną. Z tego też względu, wydaje się, że Patriarchat Konstantynopola na własną rękę stara się dać możliwość zawarcia związku małżeńskiego osobom duchownym, którzy stracili żony. Decyzją św. Synodu Patriarchatu Konstantynopola z 3 września 2018 roku zezwolono, aby owdowiali duchowni mogli ponownie wstępować w związek małżeński ${ }^{26}$. Decyzja ta wywołała pewną konsternację w świecie prawosławnym. Z jednej strony narusza ona tradycję kanoniczną, z drugiej zaś przeczy decyzjom wspólnie podjętym dwa lata wcześniej na Wielkim Soborze Kościoła Prawosławnego.

\subsection{Małżeństwa mieszane}

Problem małżeństw mieszanych jest wyrazem żywej i aktualnej troski duszpasterskiej wszystkich chrześcijan. Sygnatariusze dokumentu z Krety próbując rozwiązać to zagadnienie wyrażają się dość ambiwalentnie na ten temat. W pierwszej części paragrafu czytamy: „Małżeństwo prawosławnych z nieprawosławnymi jest zakazane, zgodnie z kanoniczną akrybiją" (II,5a). Przy tym w tekście znajdujemy odwołanie się do kanonu 72 in Trullo. Kanon nie jest cytowany, lecz jedynie przywołany w formie kościelnej normy. Treść tego kanonu zakazuje zawierania związków małżeńskich z heretykami: „Nie godzi się, aby ortodoksyjny mąż wstępował w związki małżeńskie z kobietą heretyczką, ani też ortodoksyjna kobieta wiązała się małżeństwem $\mathrm{z}$ heretykiem. Jeżeli jednak ujawni się, że coś podobnego zostało dokonane, należy uważać związek małżeński za nieważny i niegodziwe pożycie rozwiązać" ${ }^{27}$. W dokumencie nie występuje określenie współczesnych chrześcijan należących do innych Kościołów mianem heretyków, jednak zastosowanie takiego języka w argumentacji może

\footnotetext{
26 Por. Le Patriarcat de Constantinople va autoriser un second mariage pour les prêtres, https://orthodoxie.com/ le-patriarcat-de-constantinople-va-autoriser-un-second-mariage-pour-les-pretres/ [dostęp 24.05.2021].

27 Kanony Kościoła Prawosławnego..., s. 96.
} 
znacząco komplikować relacje międzychrześcijańskie. O ile pierwsza część paragrafu odnosi się krytycznie do zagadnienia małżeństw mieszanych, to w drugiej części dokumentu czytamy: „Możliwość zastosowania kościelnej ekonomii w odniesieniu do przeszkód w zawarciu małżeństwa powinna być rozpatrywana przez Święty Synod poszczególnych autokefalicznych Kościołów prawosławnych, zgodnie z zasadami świętych kanonów w duchu duszpasterskiej rozważności w celu zbawienia człowieka" (II,5b). Innymi słowy mówiąc, Sobór przyjmuje generalną linię wskazującą na nieprawidłowość zawierania związków małżeńskich, z drugiej zaś daje swobodę poszczególnym Kościołom w kwestii samodzielnego decydowania o takich małżeństwach.

Należy zauważyć, że linia, która została nakreślona przez uczestników Soboru na Krecie, jest linią twardą. Projekt dokumentu „Przeszkody małżeńskie” z 1982 roku nieco inaczej formułował zagadnienie małżeństw mieszanych wyznaniowo: „(...) może być ono zawierane ze względu na wyrozumiałość i miłość do człowieka, pod warunkiem, że dzieci zrodzone z tego małżeństwa zostaną ochrzczone i wychowane w Kościele prawosławnym. Lokalne Kościoły prawosławne moga podejmować decyzje odnośnie do zastosowania w konkretnych przypadkach ekonomii zależnie od swoich potrzeb duszpasterskich" ${ }^{28}$. Podobne wyrażenia zawierał projekt dokumentu zatwierdzony przez Synaksę zwierzchników w styczniu 2016 roku w Chambésy, wskazując na trudności kanoniczne w zawieraniu takich związków (powołując się również na in Trullo 72), jednak dopuszczając takie związki, warunkując to zasadami takimi, jak dokument z 1982 roku $^{29}$. Brak w miarę pozytywnego podejścia do związków mieszanych wyznaniowo może nieco dziwić w ostatecznej wersji dokumentu. Przyczynę

\footnotetext{
28 Przeszkody małżeńskie..., s. 399

29 „Małżeństwo między prawosławnymi i nieprawosławnymi nie może być zawierane, według reguł kanonicznych (akrybii, in Trullo 72). Jednakże może ono być zawarte ze względu na wyrozumiałość i miłość do człowieka, pod warunkiem, że dzieci zrodzone z tego małżeństwa zostaną ochrzczone i wychowane w Kościele prawosławnym”. Tłum. T. KAŁUŻny, w: Przed Soborem Wszechprawosławnym..., s. 271.
} 
zaistniałej sytuacji należy upatrywać w dyskusji, która toczyła się jeszcze w procesie przygotowawczym. Dyskusja ta związana była ze znacznymi rozbieżnościami w postrzeganiu tego zagadnienia w poszczególnych autokefalicznych Kościołach lokalnych. Rozbieżności te wynikają z sytuacji, nazwijmy, geo-eklezjalnej. Główny problem $\mathrm{w}$ postrzeganiu tego zagadnienia pojawił się w ustosunkowaniu się do sytuacji występującej w Kościele gruzińskim. Kościół ten jest dość monolityczny i tradycyjny. Jeśli problem małżeństw mieszanych w nim istnieje, to raczej jest on mało znaczącym i można przypuszczać, że takie małżeństwa zdarzają się w Gruzji nieczęsto. W procesie przygotowawczym do Soboru Kościół gruziński ciągle wykazywał tendencję wyraźnego sprzeciwu do zapisu pozwalającego na zawieranie związków mieszanych. Również oficjalną przyczyną odmowy udziału Kościoła gruzińskiego w Soborze było „zagrożenie” legalizacji związków mieszanych wyznaniowo ${ }^{30}$. Dlatego też przewodniczący Soboru Patriarcha Ekumeniczny Bartłomiej zdecydował się przedstawić Soborowi do akceptacji dość twarde stanowisko Patriarchatu Gruzji, jako ujęcie jego głosu. Takie sformułowanie zostało zresztą zaakceptowane $^{31}$.

Na końcu dokumentu jednoznacznie stwierdza się, że związki małżeńskie z niechrześcijanami nie mogą mieć wymiaru sakramentalnego: „Małżeństwo prawosławnych z niechrześcijanami jest, zgodnie z kanoniczną akrybija zakazane" (II,5c). Sygnatariusze dokumentu wyraźnie zrezygnowali z klauzuli, która była proponowana w projekcie dokumentu ze stycznia 2016 roku: „Stosowanie ekonomii kościelnej zostaje określone przez Święty Synod każdego autokefalicznego Kościoła prawosławnego, zgodnie z zasadami wynikającymi z kanonów kościelnych, w duchu duszpasterskiej troski o zbawienie

30 Dnia 23 czerwca w godzinach popołudniowych przewodniczący Soboru, patriarcha Ekumeniczny Bartłomiej, odczytał list, który został przesłany Soborowi przez patriarchę Gruzji, Eliasza. W liście tym została wyrażona właśnie taka przyczyna odmowy udziału gruzińskiej delegacji w obradach Soboru.

31 Należy dodać, że w procesie przygotowawczym zupełnie odmienny głos od Kościoła gruzińskiego przedstawiała delegacja Kościoła antiocheńskiego. 
człowieka" ${ }^{32}$. W dokumencie przyjętym przez Sobór zamieszczono jedynie klauzulę wskazującą: „praktyka podczas stosowania tradycji kościelnej w zakresie przeszkód do zawarcia małżeństwa powinna też brać pod uwagę odnośne przepisy prawne każdego państwa, nie przekraczając granic kościelnej ekonomii” (II,6).

\section{Podsumowanie}

Właściwie, przyjęty na Soborze 2016 roku dokument nie stanowi jakiegoś nowego ujęcia zagadnienia, a jedynie potwierdza już funkcjonujące rozwiązania i ustalenia w dziedzinie zawierania związków małżeńskich. Dyskusja jednak na ten temat jest potrzebna, zwłaszcza w świetle coraz większej liczby związków mieszanych wyznaniowo i przyjętej przez Patriarchat Ekumeniczny decyzji o możliwości ponownego zawarcia małżeństwa przez osobę duchowną, tj. prezbitera lub diakona.

\section{References}

\section{Źródła}

Decyzja Zwierzchników Cerkwi Prawosławnych, Wiadomości Polskiego Autokefalicznego Kościoła Prawosławnego (2014) nr 4, s.3.

Kanony Kościoła Prawosławnego, tłum. A. Znosko, Hajnówka 2000.

Przeszkody małżeńskie. Tekst przyjęty przez II Ogólnoprawosławną Konferencję Przedsoborową - Chambésy 1982, w: T. KA£UŻNY, Nowy Sobór Ogólnoprawosławny, Kraków 2008.

Sakrament małżeństwa i jego przeszkody. Tekst przyjęty przez Święty i Wielki Sobór Kościoła Prawosławnego, Kreta 18-26.06.2016 w: Cerkiewny Wiestnik, Wydawnictwo Warszawskiej Metropolii Prawosławnej (2016) nr 4, s. 50-53.

Sakrament małżeństwa i przeszkody do jego zawarcia. Tekst przyjęty przez uczestników zgromadzenia (Synaxis) zwierzchników autokefalicznych Kościołów prawosławnych (Chambésy 2016), tłum. pol. T. KaŁUŻNY, w: T. KAŁUŻNY, Z. KIJAS (red.), Przed Soborem Wszechprawosławnym, red., Kraków 2016, s. 267-271.

${ }^{32}$ Sakrament małżeństwa i przeszkody..., s. 271. 
Synaksa Zwierzchników Lokalnych Cerkwi Prawosławnych, Chambésy (21-28 stycznia 2016), Wiadomości Polskiego Autokefalicznego Kościoła Prawosławnego (2016) nr 3.

Synodica III, Secretariat pour la preparation du Saint et Grande Concile de l'Eglise Orthodoxe, Chambésy- Genève 1979.

Synodica VIII, Secretariat pour la preparation du Saint et Grande Concile de l'Eglise Orthodoxe, Chambésy- Genève 1994.

\section{Literatura}

Hrycuniak S., Prawosławne pojmowanie małżeństwa, Białystok 1994.

KuźmA A., Małżeństwo w projektach dokumentów na Wszechprawosławny Sobór, ELPIS 16 (2016), s. 177-182.

Kuźma A., Trzecie spotkanie Komisji Przygotowawczej, Wiadomości Polskiego Autokefalicznego Kościoła Prawosławnego (2015) nr 5.

Kuźma A., Wielki Sobór Kościoła Prawosławnego na Krecie w 2016 r. i jego ustalenia, ELPIS 20 (2018), s. 165-179.

Meyendorff J., Małżeństwo w prawosławiu. Liturgia teologia, życie, tłum. pol. K. LEŚNIEWSKI, Lublin 1995.

Znosko A., Prawosławne Prawo Kościelne, cz. II, Warszawa 1975.

\section{Inne materiały}

Le Patriarcat de Constantinople va autoriser un second mariage pour les prêtres, https://orthodoxie .com/le-patriarcat -de-constantinople- va-autoriser-un-second-mariage-pour-les-pretres/ [dostęp 5.05.2021].

Official Documents of the Holy and Great Council of the Orthodox Church, https:// www.holycouncil.org/official-documents [dostęp 5.05.2021].

\section{Nota o autorze}

Ks. Andrzej Kuźma - polski duchowny prawosławny, ksiądz protojerej Polskiego Autokefalicznego Kościoła Prawosławnego, doktor nauk teologicznych, wykładowca akademicki Chrześcijańskiej Akademii Teologicznej w Warszawie (ChAT). 